\title{
Advances in the knowledge of the natural history of aquatic plants in the Neotropics
}

\author{
Edson Gomes de Moura Júnior ${ }^{*^{*}}$ (D) , Suzana Neves Moreira² ${ }^{\text {(D), Aline Lopes }}{ }^{3}$ (D), Marco Otávio Dias Pivari ${ }^{4}$ (D), \\ Maria Cecilia Chiara Moço ${ }^{5}$ (D) Vali Joana Pott ${ }^{6}$ (i) and Arnildo Pott ${ }^{6}$ (D)
}

Received: February 19, 2021

Accepted: April 2, 2021

\begin{abstract}
Until the mid-XX century, little awareness on the ecological services or socio-environmental problems and benefits related to aquatic plants culminated in bottlenecks on their natural history, especially for the Neotropics. In this context, Acta Botanica Brasilica (ABB) organized this special issue to promote the advancement of knowledge on this ecological group in the Neotropics, supported by Sociedade Botânica do Brasil's group of aquatic plants specialists. We selected and evaluated manuscripts gathering unprecedented findings, resulting from studies on aquatic plants, with little investigated or documented approaches, such as the improper use of methodological paradigms and aspects of biogeography, ecophysiology, morphoanatomy, structuration of communities, functional ecology, and human use. Here we present a synthesis of these reports' findings that shall contribute to deepening the knowledge on the natural history, sustainable use, and conservation of aquatic plants and guide future research, mainly in Neotropical aquatic ecosystems. The publication of special issues on themes with insufficient knowledge to Science can reduce such gaps and expand the journal's perspectives. Therefore, we believe that this special issue of ABB will boost the understanding of aquatic plants' natural history as much as incentivizing journals with specific scopes of the area of Plant Biology to similar initiatives.
\end{abstract}

Keywords: aquatic ecosystems, aquatic macrophytes, biodiversity conservation, hydrophytes, research trends, sustainable use

\footnotetext{
1 Núcleo de Ecologia e Monitoramento Ambiental, Universidade Federal do Vale do São Francisco, 56300-000, Petrolina, PE, Brazil

2 Universidade Estadual de Mato Grosso do Sul, 79400-000, Coxim, MS, Brazil

3 Instituto de Ciências Biológicas, Universidade de Brasília, 70910-900, Brasília, DF, Brazil

4 Herbário do Parque Estadual do Rio Doce, Parque Estadual do Rio Doce, Instituto Estadual de Florestas, 35185-000, Marliéria, MG, Brazil

5 Herbarium CGMS, Universidade Federal do Rio Grande do Sul, 91501-970, Porto Alegre, RS, Brazil

6 Instituto de Biociências, Universidade Federal de Mato Grosso do Sul, 79070-900, Campo Grande, MS, Brazil
}

* Corresponding author: mourajunioreg@gmail.com 


\section{Introduction}

Until the first half of the XX century, aquatic plants, also called aquatic macrophytes or hydrophytes, were a somewhat neglected ecological group in limnology (Sculthorpe 1967; Tundisi \& Tundisi 2008; Thomaz \& Esteves 2011). A significant part of that neglect is attributed to unawareness of early limnologists and ecologists about these plants' ecological services in the continental aquatic ecosystems (Junk \& Howard-Williams 1984; Chambers et al. 2008; O'Hare et al. 2018). However, the present opinions of limnologists and ecologists on aquatic plants contrast with the previous concept. The knowledge acquired over the last five decades on the uses of aquatic plants, the socioenvironmental problems associated with them and their importance in maintaining ecological processes in aquatic ecosystems was fundamental for such change of attitude (Thomaz \& Esteves 2011).

Although early findings on aquatic plants were documented in the first half of the XX century (Piedade et al. 2010; Thomaz \& Esteves 2011), investigations on these plants only became more expressive after 1970s mainly in Europe or North America (Fig 1A). In the following decade, the first studies on Neotropical aquatic plants were recorded (Fig. 1A). From 1945 to 2000, over 35,000 documents on aquatic plants and equivalent terms were published (Web of Science 2021). Of this total, ca. 16,000 were recorded for European countries, 10,000 for North American countries, and a little over 3,000 for Neotropical countries (Web of Science 2021). However, the proportion of publications on aquatic plants for the Neotropics, compared with European and North America, has increased over time (Fig. 1B). The high taxonomic diversity and endemism of aquatic plants in the Neotropical Ecozone (Murphy et al. 2019; 2020), associated with the growing number of aquatic plant researchers ("macrofiteiros") in South America during the XXI century (Machado-Filho et al. 2014), probably influenced this increased interest. Most published studies on aquatic plants in the Neotropics were developed in Brazilian territory (Fig. 2A), promoted mainly by institutions or researchers working in this country. (Fig. 2 B,C).

Despite aquatic plants taxonomic diversity in Neotropical ecosystems being well-documented (Machado-Filho et al. 2014), knowledge gaps can be found in that Ecozone. Currently, few studies focus on morphoanatomy, cell biology, and physiology involving aquatic plants in the Neotropic Ecozone (Fig. 2D). Furthermore, studies addressing the methodological paradigms (Dalla-Vecchia et al. 2020; Moura-Júnior et al. 2021a), analyzing macroecological and biogeographic patterns (Lopes et al. 2017; Pulzatto et al. 2019; Murphy et al. 2019; 2020), or the functional ecology of these plants in Neotropical ecosystems (Moreira et al. 2015; Lopes et al. 2016; Catian et al. 2018; Carvalho et al. 2020), are still incipient. Studies on the management of invasive aquatic macrophytes or the phytochemical characterization and application of aquatic plant species for commercial uses are also nearly inexistent in the Neotropics (Padial et al. 2008). The low number of investigations in those research lines has limited the advancement of knowledge on the natural history, conservation biology and sustainable use of aquatic plants.


Figure 1. Number $(\mathbf{A})$ and percentage $(\mathbf{B})$ of records of documents published between 1970 and 2020 involving aquatic plants in Europe, North America and Neotropical countries, according to the data base of the main collection of Web of Science (https:// https://apps.webofknowledge.com). Search made on $7^{\text {th }}$ February 2021 utilizing the following combination of words: aquatic plant* or aquatic plants* or macrophytes* or macrophyte* or aquatic macrophytes* or aquatic macrophyte* or hydrophytes* hydrophyte.

During the early 1990s, aquatic plants researchers created inside the Sociedade Botânica do Brasil - SBB (in English, Brazilian Botanical Society), a Commission of Aquatic Plants Specialists, which in 2012 was transformed into the Núcleo de Especialistas em Plantas Aquáticas NEPA (in English, Group of Aquatic Plants Specialists), to promote and encourage national studies on this plant group, contributing the advancement of knowledge in the field. The Aquatic Plants of Brazil data repository was one of the recent products resulting from projects developed by NEPASBB (Pivari et al. 2019). In this database, NEPA researchers 
compiled, systematized, and made available taxonomic, ecological and biogeographic data on the aquatic plants from Brazil, obtained mainly from previous taxonomic studies (Pivari et al. 2019). The virtual platform was launched in 2018 (https://sites.icb.ufmg.br/plantasaquaticasbrasil/), together with the publication of the data from Southeastern Brazil (Pivari et al. 2019). The first census of aquatic plants of Northeastern (Moura-Júnior et al. 2013), Northern (Moura-Júnior et al. 2015), and Southern Brazil (Oliveira et al. 2019), as well as the updated list for the Northeastern region (Moura-Júnior \& Cotarelli 2019), are amongst the publications associated with the data repository project.

Although the NEPA-SBB projects have generated considerable advances regarding the knowledge of the taxonomic diversity of aquatic plants in Brazil, several gaps remain in these plants' natural history for the Neotropics, as we previously showed. Scientific dissemination can have a fundamental role in the reduction of knowledge gaps. Previous initiatives for disseminating scientific knowledge on Neotropical aquatic plants were promoted by the journals Rodriguésia in 2011 (https://rodriguesia-seer.jbrj.gov.br/ index.php/rodriguesia/issue/view/9), and Oecologia Australis in 2019 (https://doi.org/10.4257/oeco.2019.2304; https:// revistas.ufrj.br/index.php/oa/issue/view/1373/showToc).

In the interest of aiding NEPA-SBB to face the current challenges, Acta Botanica Brasilica (ABB) reserved the first fascicle of 2021 for the scientific dissemination of unprecedented findings on aquatic plants in the Neotropics. In the following text, we will provide a synthesis of the articles published in the present issue of $\mathrm{ABB}$. We concentrated on the following key study areas, organizing them into sections in this manuscript: (i) Methodological paradigms; (ii) Large scale spatial ecology; (iii) Functional ecology in metacommunities; (iv) Relation between the type
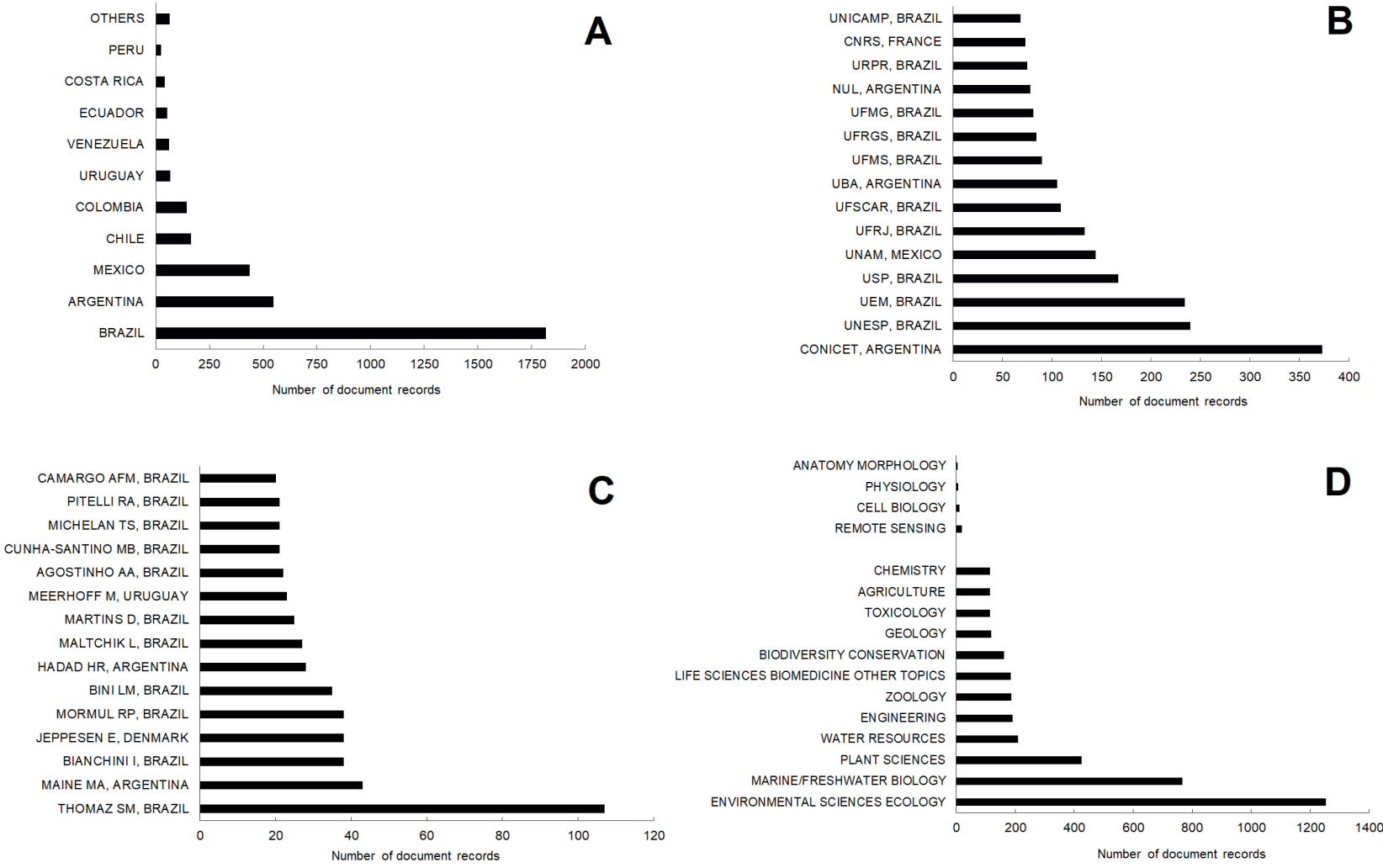

Figure 2. Number of records of published documents between 1970 and 2020 involving aquatic plants in the Neotropical ecozone, according to the data base of the principal collection of Web of Science (https://apps.webofknowledge.com). Search made on $7^{\text {th }}$ February 2021 utilizing the following combination of words: aquatic plant* or aquatic plants* or macrophytes* or macrophyte* or aquatic macrophytes* or aquatic macrophyte* or hydrophytes* or hydrophyte*. We filtered the results of the search for Neotropical countries $(\mathbf{A})$ and, next, we analyzed the records per institution, author and research line. The results of the graphs $\mathbf{B}$ and $\mathbf{C}$ show, respectively, the number of records obtained for the 15 institutions and researchers with highest contribution among documents linked to Neotropical countries. Graph $\mathbf{D}$ points the main research lines approached in the documents, and indicated comparatively the low number of studies on anatomy, morphology, cell biology, physiology and remote sensing of this group of plants in the Neotropics. Captions: (CONICET) - Consejo Nacional de Investigaciones Cientificas Y Tecnicas; (UNESP) - Universidade Estadual Paulista; (UEM) Universidade Estadual de Maringa; (USP) - Universidade de São Paulo; (UNAM) - Universidad Nacional Autónoma de México; (UFRJ) - Universidade Federal do Rio de Janeiro; (UFSCAR) - Universidade Federal de São Carlos; (UBA) - University of Buenos Aires; (UFMS) - Universidade Federal de Mato Grosso do Sul; (UFRGS ) -Universidade Federal do Rio Grande do Sul; (UFMG) - Universidade Federal de Minas Gerais; (NUL) - National University of the Littoral; (UFPR) - Universidade Federal do Paraná; (CNRS) - Centre National De La Recherche Scientifique; (UNICAMP) - Universidade Estadual de Campinas. 
of habitat and structuration of riparian communities; (v) Relation between habitat type and environmental filters with morphoanatomy and physiology; (vi) Studies applied to the management of invasive species and sustainable use; and (vii) Relation of aquatic plants with the restoration of aquatic ecosystems.

\section{Contributions to the natural history of aquatic plants in the Neotropics}

\section{Methodological paradigms}

The investigation methods utilized for biological or ecological studies follow the paradigms of the best-studied taxonomic groups (Giannini et al. 2012; Tirintan et al. 2018). However, we are aware of the inexistence of a methodological pattern that complies with all species' particularities. Many investigation methods utilized for biological or ecological studies involving aquatic plants follow methodological paradigms thought for terrestrial plants (Cancian \& Camargo 2011; Tirintan et al. 2018). Given the taxonomic and life form diversity of aquatic plants (Pott \& Pott 2000; Moreira et al. 2017; Murphy et al. 2020) and the ecological and ecophysiological particularity of each species (Thomaz \& Esteves 2011), it is possible to infer that using methods designed for terrestrial plants in studies involving aquatic plants can be disastrous. Two articles presented in this issue of $A B B$ propose methodological innovations for modeling the potential distribution or taxonomic identification of aquatic plants.

Moura-Júnior et al. (2021b) analyzed the applicability of bioclimatic or limnological layers for the Species Distribution Modelling (SDM) of aquatic plants on a local spatial scale. The use of bioclimatic layers elaborated from the interpolation of data obtained for gross spatial scales can hinder the SDM of aquatic plants. For such situations, they observed that the computed models with limnological layers elaborated from the interpolation of field data to a fine spatial scale showed excellent performances. However, the decision on the elaboration and use of this type of limnological layer in the SDM of aquatic plants needs to consider the cost-benefit of obtaining field data and the application of modeling.

Regarding the difficulty to access wetlands during flood season and the possibility of identifying the species using the seed bank, Bao \& Bambil (2021) analyzed computational images to extract morphological information on seeds. They tested the ability of deep learning algorithms, support vector machine-SVM, and random forest to solve the problem of classifying the seeds of twelve species of aquatic plants. They analyzed seed color, shape and texture. The computational vision proved efficient in species classification for SVM (97.91\%), random forest (97.08\%), and deep learning
(92.5\%). The study showed that the utilization of algorithms is efficient to improve the precision rate of the classification of aquatic plant seeds. This is a significant advancement to access biodiversity and establish better conservation strategies for wetlands.

\section{Large spatial scale ecology}

Developments in macroecological analysis tools have fostered knowledge on the taxonomic diversity and endemism of aquatic plants in different ecozones (Murphy et al. 2019; 2020), as well as these plants' relation with environmental predictors in different spatial scales (O'Hare et al. 2018). Studies with this approach can be applied to interpret a species' biogeographical or ecological niche on a local or regional scale and conservation of this group of plants on macroscales (O'Hare et al. 2018). Species richness and distribution patterns or the selection of environmental predictors for the occurrence of aquatic plants in different spatial scales are approaches that have recently caught the interest of ecologists (Moreira et al. 2015; Lopes et al. 2016; Moura-Júnior \& Cotarelli 2019; Oliveira et al. 2019; Pulzato et al. 2019; Murphy et al. 2020; Moura-Júnior et al. 2021a). Three manuscripts published in this ABB issue report investigations on some of these approaches.

Lopes et al. (2021) utilized SDM techniques to test the hypothesis that the potential distribution of species in the PELD-MAUA sites (Long Term Ecological Research; https://peld-maua.inpa.gov.br) of black water igapós in Jaú National Park are much wider (i.e., Neotropical) than species of floodable white-sand campinaranas (i.e., restricted to the Amazon Basin) in the Sustainable Development Reserve of Uatumã. Studies on these Amazon wetlands are still incipient, especially on a macroscale (Piedade et al. 2010; Lopes et al. 2017; 2019). The study demonstrated that the environmental variables were able to efficiently predict the potential distribution for all analyzed species in the PELDMAUA sites. Herbaceous species found in the igapó tend to be widely distributed in the Neotropical region, showing high connectivity of environments and indicating the absence of dispersion barriers. In contrast, most campinarana species have their potential distribution more restricted to the Amazon Basin, probably due to these habitats' distribution being insular and fragmented, intercalated with the Amazon Forest. A reduced floristic similarity of $<1 \%$ was observed between campinarana and igapós of both PELD-MAUA sites, indicating that local environmental factors linked to hydrology, soils and disturbance need to be better investigated. The authors point to other possibilities of studies, e.g., the need to understand those characteristics at a local level, mainly in floodable campinaranas, to establish proper managing plans at a local and regional level.

Mori et al. (2021) evaluated the influence of variables related to three spatial scales (local, river channel and landscape) on the occurrence or composition of aquatic plants in stretches of a tropical river that did not undergo 
regular floods. The variables recorded for each analyzed spatial scale were: Local - water chemical and physical variables; Channel - morphometric characteristics of the channel, plus phosphorous and nitrogen content in the sediment; Landscape - canopy opening, terrain elevation, and land use categories. They found that water chemical conditions and channel morphometry (e.g., depth and margin slope) were relevant variables to explain the species occurrence in the river stretches, while landscape measures had little influence on species composition.

Matias et al. (2021) presented a new approach to the lentic systems in the Brazilian semiarid region. Albeit the semiarid has hydrographic basins with little drainage, reflected in few permanent and lotic systems, various lakes occur, either permanently or seasonally. The aquatic plants in these systems have wide distribution. However, the authors tested the hypothesis that higher species richness and more growth habits are found in lentic systems than lotic ones. They analyzed 1,619 records of aquatic Angiosperms in 43 wetlands of the semiarid. The richest families were Cyperaceae, Poaceae, Fabaceae, Alismataceae, Malvaceae, Nymphaeaceae, and Pontederiaceae, which corroborated previous studies on aquatic environments. The hypothesis was partially confirmed since lentic systems were shown to have the highest exclusive species richness. However, the richness of different habits was not confirmed, though all inventoried areas somehow contributed to the species richness. Thus, aquatic flora conservation must be comprehensive so that all freshwater habitats in the Brazilian semiarid region are protected.

\section{Functional ecology in metacommunities}

Knowing the patterns of assembling metacommunities of aquatic plants based on functional attributes' response to environmental gradients allows both functional and taxonomic understanding of these communities (García-Girón et al. 2019). Although the relation between environmental filters and taxonomic or functional composition of plant communities is well documented, the response of each type of composition in the same environmental gradient needs to be better clarified for aquatic plant communities (García-Girón et al. 2019). The study by Pereto \& Padial (2021), published in ABB's present issue, analyzed the spatial variation in the functional composition of assemblages of aquatic plants in a Neotropical floodplain considering subsystems with documented different plant taxonomic composition. Contrary to their expectations, there were only minor differences in functional composition between the investigated subsystems. They found little evidence that a particular aquatic plant assemblage is associated with specific subsystem. Thus, the authors suggested that the environmental heterogeneity was only reflected in the taxonomy but not in the investigated metacommunities' functional composition.

\section{Relation between the type of habitat and structuration of riparian communities}

The interaction between aquatic plants, water flow, and sediment has motivated many studies in the last four decades (O'Hare et al. 2018). However, the significant increase in publications on this subject was perceived only in the last decade, as the importance of these interactions for ecology, hydrology, and fluvial geomorphology was recognized. "Physical habitat interactions and riparian processes" is considered one of the ten present and future research trends on aquatic plants in Europe (O'Hare et al. 2018). The relation between water level variation (regulated or natural), the cultivation of exotic riparian plants, and colonization and growth of native aquatic plants are matters of the highest relevance for this subject in the Old World (O'Hare et al. 2018). However, such relations in the Neotropical regions' aquatic ecosystems need to be better explained (Bao et al. 2014; 2015).

In the present $\mathrm{ABB}$ issue, one of the publications addressed this issue. Bao et al. (2021) evaluated the relation between seed bank and the diversity of native aquatic plants in flooded grassland in the Brazilian Pantanal, where exotic plants dominated the standing vegetation. They found that the seed bank showed potential to maintain the diversity of native species of this community once the natural flood cycle, typical of the Brazilian Pantanal, promoted the establishment of native, mainly aquatic, plants recruited from the seed bank.

\section{Relation between habitat type and environmental filters with morphoanatomy and physiology}

Although the relation between aquatic plants and ecological stoichiometry of aquatic ecosystems is already understood, the elementary requirements of nutrient absorption and, consequently, the development of morphoanatomical traits or production of reproductive structures of these plants are far from being fully clarified (O'Hare et al. 2018). Notably, there is a lack of research on the relationship between hydrological, limnological, and sediment conditions with the anatomy, phenology, and physiology of aquatic plants, which can jeopardize the understanding of the aquatic plants' functions (DallaVecchia et al. 2020). Five manuscripts presented in this ABB issue made investigations with these approaches.

Leandro et al. (2021) investigated responses and phenotypical strategies concerning life form and morphoanatomy of two sympatric species (Pontederia azurea Sw. and P. crassipes Mart.) in moderately dry and aquatic habitats in the Brazilian Pantanal. They recorded a reduction of lacunae area, increased thickness in the cell walls of vessel elements, the storage of starch grains in the sheath cells of the vascular bundle, and star-shaped cells as phenotypical responses associated with moderately dry habitats. Alternatively, petiole length, leaf-blade size, lacunae area, 
and lignification degree were related to fluctuations in the water level. The species share some morpho-anatomical responses regardless of the environment, such as the presence of aerenchyma and storage of starch granules, which provides evidence that these phenotypic convergences are adaptive. Thus, the phenotypic responses observed in the present study provide evidence of how plant structure can simultaneously reflect phylogeny and ecology.

To describe the reproductive phenology of aquatic plants, Simão et al. (2021) analyzed 15 species with various lifeforms. They verified how aquatic plants relate to climatic factors and physicochemical water variables in two lakes in the Cerrado-Pantanal ecotone, Central-Western Brazil. They observed that the photoperiod stood out among the climatic variables that explain the species' phenophases. The water physical-chemical variables influenced the fructification patterns. Nitrogen and phosphorous, in high concentrations in eutrophicated habitats, can alter some species' reproductive patterns. Such information is relevant to understand how alterations in the water properties caused by pollution, eutrophication, silting, and others can alter aquatic plants' phenology.

Chiba-de-Castro et al. (2021a) compared the quality, decomposition, and enzymatic activity of litter made from Egeria densa Planch. (native) and Hydrilla verticillata (L. f.) Royle (exotic invasive). The invasive species had higher lignin content and lower cellulose content than the native species. Both plants did not show differences in enzymatic activity over time, although $E$. densa showed higher enzymatic efficiency than $H$. verticillata. The authors claim that this differential enzymatic performance can lead to changes in invaded waters' mineralization processes. Thus, the lower decomposition rates of the invasive species' litter, associated with litter quality differences, can increase the organic material particles and alter debris of different trophic levels in invaded habitats.

Souza et al. (2021) evaluated the implications of global climate change (temperature and increased $\mathrm{CO}_{2}$ ) in the development and ecological interactions between two widely distributed species in the Amazon Forest, Eichhornia crassipes (Mart.) Solms and Pistia stratiotes L. The authors simulated situations with treatments of different temperatures and $\mathrm{CO}_{2}$ concentrations (light, intermediate, and extreme), and analyzed the effects on growth, physiological aspects and ecological interactions between them. The increase in temperature and $\mathrm{CO}_{2}$ concentration negatively affected the morphology and physiology of E. crassipes and P. stratiotes. In contrast, in $P$. stratiotes, the adverse effects were observed under lower temperatures than E. crassipes. The authors state that the obtained data indicate that these species are vulnerable to the foreseen global climate change, either individually or in complex interrelations.

Chiba-de-Castro et al. (2021b) investigated the microstructure of the rhizomes of the invasive Hedychium coronarium J.König (Zingiberaceae) under different soil moisture conditions. The rhizome fragments came from wet and dry riverine areas dominated by the species in Southeastern Brazil. The results demonstrated that only the wet areas rhizomes formed aerenchyma, while those of dry areas stored more starch. The authors remind us that plants commonly show anaerobic metabolism in wet habitats, corroborated by low starch contents. However, the aerenchyma contributes to the high performance of $H$. coronarium in flooded soils. The results indicate that the rhizomes could play an essential role in the dominance of $H$. coronarium in Neotropical riparian areas. Further studies are suggested to investigate the rhizomes' competitive capacity.

\section{Studies applied to the management of invasive species and sustainable use}

Studies that analyzed environmental filters associating limnological, hydrological, and sedimentological conditions with the occurrence or productivity of aquatic plants are widely documented for Neotropical ecosystems since the early XX century (Padial et al. 2008). However, the application of such studies in the management of invasive aquatic plant species is still incipient, as well as studies focusing on the sustainable use of widely distributed and abundant species with already known traditional uses (Padial et al. 2008). Such observation highlights how far Neotropical countries' governments are from accomplishing the targets they assumed for the conservation and sustainable use of biodiversity, e.g., during the Aichi Convention on Biological Diversity (CBD 2021). The $2^{\text {nd }}$ goal from the CBD's strategic objective A establishes that, until 2020, signatory countries should recognize their biodiversity's values and integrate them into their national human development and poverty reduction strategies.

In the present $\mathrm{ABB}$ issue, three publications discussed the management of invasive aquatic species or the sustainable use of species with traditional uses. Ferreira et al. (2021) assessed the biomass production and level of nutrients in fronds of Ceratopteris pteridoides (Hook.) Hieron. (Pteridaceae) with treatments with or without the addition of a nutritive solution. This aquatic fern is widely distributed in the Amazon Basin and is a potential food source. The nutritive solution promoted extraordinary conditions for the species' growth. Chemical analyses of macro- and micronutrients indicated that the daily ingestion of $C$. pteridoides could contribute to human mineral supplementation, besides diversifying the existing crops, and enhancing sustainable family agriculture.

Florêncio et al. (2021) investigated the relationship between the maximum colonization depth $(\mathrm{Zmax})$ and biomass production of the native Egeria najas Planch. and the invasive Hydrilla verticillata within the depth gradient of a hydroelectric reservoir in Brazil. The results indicate that both species exhibit different depth adjustments, with the invasive species adjusted to deeper water under a more intense subaquatic light limitation and more wave 
disturbance. The preference of $H$. verticillata for deeper places, it has an elevated potential to occupy large areas and accumulate biomass in the dam, causing severe damages to the ecosystem and economic loss to the hydroelectric. For management, water level regulation is recommended as a physical strategy to prevent its infestations in the reservoir.

Sato et al. (2021) analyzed the effects of the invasive grass, Urochloa arrecta (Hack. ex T.Durand \& Schinz) Morrone \& Zuloaga, on the biodiversity of native aquatic plants in two spatial scales. Urochloa arrecta is one of the most aggressive aquatic weeds in Brazilian freshwater ecosystems. Species richness was lower in aquatic plants stands dominated by $U$. arrecta, indicating a prominent biotic homogenization. The authors conclude that $U$. arrecta is a species not limited by geographic barriers due to human transportation and for being an engineer species in aquatic ecosystems. Furthermore, the expansion of $U$. arrecta in tropical rivers will probably eliminate part of the native aquatic plants, leading to severe consequences in these ecosystems. Therefore, monitoring and controlling this exotic species are considered urgent in Brazilian freshwater ecosystems.

\section{Relation of aquatic plants with the restoration of aquatic ecosystems}

The degradation of fresh or brackish water ecosystems due to natural and anthropogenic impacts is a growing problem worldwide, impairing environmental quality and the ecological services of these ecosystems (Harkes et al. 2015; Ecke et al. 2016). The reduction of diversity and biomass of aquatic plants caused by such impacts can cause disastrous cascade ecosystem effects due to these plants' importance as habitat to other groups of organisms and metabolism and nutrient cycling in water bodies (Tundisi \& Tundisi 2008; Thomaz \& Esteves 2011). Therefore, ecological and biochemical studies on aquatic plants are essential tools for the restoration of continental and coastal aquatic ecosystems (Harkes et al. 2015; Ecke et al. 2016). However, restoration science is still under development, and new data are necessary for all types of aquatic ecosystems (O'Hare et al. 2018), mainly for brackish water systems, such as mangroves and estuaries (Ecke et al. 2016).

The study by Silva \& Amarasinghe (2021), featured in ABB's current issue, investigated the potential use of mangroves in the rehabilitation of hypersaline habitats due to natural and anthropogenic impacts, revealing the relative capacities of species common in mangroves [e.g., Rhizophora apiculata Blume, R. mucronata Lam., Ceriops tagal (Perr.) C.B.Rob., and Avicennia marina (Forssk.) Vierh.] in removing salt from sediments and its accumulation in plant tissues. The study revealed that, out of the four investigated species, A. marina was the most efficient in retaining salt in plant tissues. That result indicates that the species can be managed in its natural habitats to protect and restore coastal landscapes affected by salinity.

\section{Conclusion}

Decisively, ABB's current volume gathers studies, many unprecedented, which approach the inefficient use of methodological paradigms, macroecological patterns, the structuration of communities, functional ecology, uses, and the physiological, morphoanatomy and biogeography aspects of aquatic plants in Neotropical ecosystems. Such contributions will deepen our knowledge on sustainable use, conservation biology, and the natural history of aquatic plants, as well as guide future research in the Neotropics. It is worth pointing out that this special issue on aquatic plants was only feasible due to ABB's interest in filling knowledge gaps on understudied plant groups. The direction adopted by the ABB's editorial committee shows that it is worthwhile to associate scientific knowledge dissemination with the expansion of a journal's publishing perspectives, consequently attracting new readers. We hope that the exuberant knowledge on the Neotropical aquatic flora presented in this volume serves as an inspiration and as methodological guidelines for further botanical, ecological, and limnological studies.

\section{Acknowledgements}

We thank ABB's editorial committee for the commitment to promote scientific knowledge, especially on Neotropical aquatic plants. We thank Dr. Pedro Eisenlohr (Editor-inChief of ABB) for the editorial support during this special issue on aquatic plants and the recommendations regarding this synthesis article. We also thank Dr. Jefferson da Cruz for giving us the symbol image [Victoria amazonica (Poepp.) J.E. Sowerby] of this special issue.

\section{References}

Bao F, Assis MA, Pott A. 2021. Maintenance of wetland plant communities: the role of the seed bank in regeneration of native plants. Acta Botanica Brasilica 35: 70-78.

Bao F, Bambil D. 2021. Applicability of computer vision in seed identification: deep learning, random forest, and support vector machine classification algorithms. Acta Botanica Brasilica 35: 17-21.

Bao F, Assis MA, Arruda R, Pott A. 2015. Effects of Urochloa humidicola on plant diversity in native grasslands in a Neotropical wetland. Wetlands 35: 841-850.

Bao F, Pott A, Ferreira FA, Arruda R. 2014. Soil seed bank of floodable native and cultivated grassland in the Pantanal wetland: effects of flood gradient, season and species invasion. Brazilian Journal of Botany 37: 239-250.

Cancian LF, Camargo AFM. 2011. Utilização de Sistemas de Informações Geográficas, softwares e algoritmos de modelagem para geração de modelos de distribuição geográfica potencial de espécies de macrófitas aquáticas em bacias hidrográficas. Boletim ABLimno 39: 1-10.

Carvalho CO, Barnhill KA, Ascenso AC, Dunck B, Teodoro GS, Michelan TS. 2020. Morphological and allometric variation due to percentage of cover in Eichhornia azurea (Swart) Kunth (Pontederiaceae). Brazilian Journal of Botany 43: 389-395.

Catian G, Silva DM, Súarez YR, Scremin-Dias E. 2018. Effects of flood pulse dynamics on functional diversity of macrophyte communities in the Pantanal Wetland. Wetlands 38: 975-991. 
Chambers PA, Lacoul P, Murphy KJ, Thomaz SM. 2008. Global diversity of aquatic macrophytes in freshwater. Hydrobiology 595: 9-26.

Chiba-de-Castro WA, Bonugli-Santos RC, Sibim AC, Cunha-Santino MB, Bianchini Jr I. 2021a. Enzymatic efficiency of the decomposing microbiota: what does really matter for aquatic macrophytes invasions? Acta Botanica Brasilica 35: 104-110.

Chiba-de-Castro WA, Almeida RV, Xavier RO, Arduin M, Moya HM, Matos DMS. 2021b. Response of rhizomes of the invasive Hedychium coronarium J. König (Zingiberaceae) to different soil moisture conditions. Acta Botanica Brasilica 35: 122-125.

CBD - Convention on Biological Diversity. 2021. Aichi Biodiversity Targets. https://www.cbd.int/sp/targets/. 05 Feb. 2021

Dalla-Vecchia A, Villa P, Bolpagni R. 2020. Functional traits in macrophyte studies: Current trends and future research agenda. Aquatic Botany 167: 103290. doi: 10.1016/j.aquabot.2020.103290

Ecke F, Hellsten S, Kohler J, Lorenz AW, Raapysjarvi J, Scheunig S, Segersten J, Baattrup-Pedersen A. 2016. The response of hydrophyte growth forms and plant strategies to river restoration. Hydrobiologia 769: 41-54.

Ferreira AB, Piedade LR, Piedade MTF, Lopes A. 2021. Biomass production of the aquatic macrophyte Ceratopteris pteridoides (Hook.) Hieron (Pteridaceae) in nutrient addition treatments. Acta Botanica Brasilica 35: 126-131.

Florêncio FM, Silveira MJ, Thomaz SM. 2021. Niche differentiation between a native and an invasive species of submersed macrophyte in a subtropical reservoir. Acta Botanica Brasilica 35: 132-139.

García-Girón J, Fernández-Aláez C, Fernández-Aláez M, Alahuhta J. 2019. Untangling the assembly of macrophyte metacommunities by means of taxonomic, functional and phylogenetic beta diversity patterns. Science of The Total Environment 693: 133616. doi: 10.1016/j.scitotenv.2019.133616

Giannini TC, Siqueira MF, Acosta AL, Barreto FC, Saraiva AM, Alves-dos-Santos I. 2012. Current challenges of species distribution predictive modelling. Rodriguésia 63: 733-749.

Harkes IHT, Drengstig A, Kumara MP, Jayasinghe JMPK, Huxham M. 2015. Shrimp aqua culture as a vehicle for Climate Compatible Development in Sri Lanka. The case of Puttalam Lagoon. Marine Policy 61: 273-283.

Junk WJ, Howard-Williams C. 1984. Ecology of aquatic macrophytes in Amazonia. In: Dumont HL. (ed.) The Amazon. Dordrecht, Springer. p. 269-293.

Leandro TD, Holsback ZR, Scremin-Dias E. 2021. The aquatic species Pontederia azurea and P. crassipes (Pontederiaceae) in the Pantanal, Brazil: evidence of how plant structure can simultaneously reflect phylogeny and ecology. Acta Botanica Brasilica 35: 79-91.

Lopes A, Demarchi LO, Franco AC, et al. 2021. Predicting the potential distribution of aquatic herbaceous plants in oligotrophic Central Amazonian wetland ecosystems. Acta Botanica Brasilica 35: 22-36.

Lopes A, Crema LC, Demarchi LO, et al. 2019. Herbáceas Aquáticas em Igapós de Água Preta Dentro e Fora de Unidades de Conservação no Estado do Amazonas. Biodiversidade Brasileira 2: 45-62.

Lopes A, Wittmann F, Schöngart J, Householder JE, Piedade MTF. 2017. Modeling of regional-and local-scale distribution of the genus Montrichardia Crueg. (Araceae). Hydrobiologia 789: 45-57.

Lopes A, Parolin P, Piedade MTF. 2016. Morphological and physiological traits of aquatic macrophytes respond to water chemistry in the Amazon Basin: an example of the genus Montrichardia Crueg (Araceae). Hydrobiologia 766: 1-15.

Machado-Filho HO, Cabral LL, Melo JIM, Zickel CS, Moura AN. 2014. Macrófitas aquáticas da região Neotropical: uma abordagem cientométrica. Revista Biociências 20: 90-106.

Matias LQ, Guedes FM, Nascimento HP, Sfair JC. 2021. Breaking the misconception of a dry and lifeless semiarid region:the diversity and distribution of aquatic flora in wetlands of the Brazilian Northeast. Acta Botanica Brasilica 35: 46-61.

Moreira SN, Assunção VA, Bueno B, et al. 2017. Aquatic macrophytes in Paraguay River branches in the Brazilian Pantanal, Mato Grosso do Sul, Brazil. Boletim do Museu Paraense Emílio Goeldi. Ciências Naturais 12: 177-185.

Moreira SN, Eisenlohr PV, Pott A, Pott VJ, Oliveira-Filho AT. 2015. Similar vegetation structure in protected and non-protected wetlands in central Brazil: conservation significance. Environmental Conservation 42: 1-7.
Mori GB, Piedade MTF, Lopes A, Ferraz SFB, Cancian LF, Camargo AFM. 2021. Different scales determine the occurrence of aquatic macrophyte species in a tropical stream. Acta Botanica Brasilica 35: 37-45.

Moura-Júnior EG, Severi W, Kamino LHY, Lemos-Filho JP. 2021a. To what degree do spatial and limnological predictors explain the occurrence of a submerged macrophyte species in lotic and semi-lotic/lentic environments of a dammed river? Limnology 22: 101-110.

Moura-Júnior EG, Nascimento FAO, Lemos-Filho JP, Severi W, Kamino LHY 2021b. Limnological layers improve species distribution modeling of aquatic macrophytes in fine-spatial resolution. Acta Botanica Brasilica 35: 9-16.

Moura-Júnior EG, Cotarelli VM. 2019. An update on the knowledge of aquatic macrophytes in Northeast Brazil. Rodriguésia 70: e04452017. doi: 10.1590/2175-7860201970076

Moura-Júnior EG, Paiva RMS, Ferreira AC, et al. 2015. Updated checklist of aquatic macrophytes from Northern Brazil. Acta Amazonica 45: 111-132.

Moura-Júnior EG, Lima LF, Silva SSL, et al. 2013. Aquatic macrophytes of Northeastern Brazil, checklist, richness, distribution and life forms. Check List 9: 298-312.

Murphy K, Carvalho P, Efremov A, et al. 2020. Latitudinal variation in global range-size of aquatic macrophyte species shows evidence for a Rapoport effect. Freshwater Biology 65: 1622-1640.

Murphy K, Efremov A, Davidson TA, et al. 2019. World distribution, diversity and endemism of aquatic macrophytes. Aquatic Botany 158: 103-127.

O'Hare MT, Aguiar FC, Asaeda T, et al. 2018. Plants in aquatic ecosystems: current trends and future directions. Hydrobiologia 812: 1-11.

Oliveira LDS, Andrade BO, Boldrini II, Chiara-Moço MCD. 2019. Aquatic vascular plants of South Brazil, checklist and a comparative floristic approach. Acta Botanica Brasilica 34: 709-715.

Padial AA, Bini LM, Thomaz SM. 2008 The study of aquatic macrophytes in Neotropics: a scientometrical view of the main trends and gaps. Brazilian Journal of Biology 68: 1051-1059.

Pereto SCAS, Padial AA. 2021. Macrophyte functional composition is stable across a strong environmental gradient of a Neotropical floodplain. Acta Botanica Brasilica 35: 62-69.

Piedade MTF, Junk W, D’Ângelo SA, et al. 2010. Aquatic herbaceous plants of the Amazon floodplains: state of the art and research needed. Acta Limnologica Brasiliensia 22: 165-178.

Pivari MOD, Melo PHA, Souza FS, et al. 2019. New initiatives for Brazilian aquatic plant data management. Acta Botanica Brasilica 33: 78-87.

Pott VJ, Pott A. 2000. Plantas Aquáticas do Pantanal. Corumbá, Embrapa.

Pulzatto MM, Cunha ER, Dainez-Filho MS, Thomaz SM. 2019. Association between the success of an invasive macrophyte, environmental variables and abundance of a competing native macrophyte.Frontiers in Plant Science 10: 514. doi: 10.3389/fpls.2019.00514

Sato RY, Costa APL, Padial AA. 2021. The invasive tropical tanner grass decreases diversity of the native aquatic macrophyte community at two scales in a subtropical tidal river. Acta Botanica Brasilica 35: 140-150.

Sculthorpe CD. 1967. The biology of aquatic vascular plants. London, UK, Edward Arnold Ltd.

Silva W, Amarasinghe M. 2021. Response of mangrove plant species to a saline gradient: Implications for ecological restoration. Acta Botanica Brasilica 35: 151-160.

Simão CH, Alves FM, Barros A, Simão PM, Pott A, Aoki C. 2021. Reproductive phenology of aquatic macrophytes in the Cerrado-Pantanal ecotone. Acta Botanica Brasilica 35: 92-103.

Souza SNG, Piedade MTF, Demarchi LO, Lopes A. 2021. Implications of global climate change for the development and ecological interactions between two key Amazonian aquatic macrophytes. Acta Botanica Brasilica 35: 111-121.

Thomaz S, Esteves FA. 2011. Comunidade de Macrófitas Aquáticas. In: Esteves FA. (ed.) Fundamentos de limnologia. Rio de Janeiro, Interciência. p. 461-518.

Tirintan G, Catian G, Luz GP, Manvailer V, Scremin-Dias E. 2018. Plântulas e sementes de macrófitas aquáticas de lagoas do Pantanal Sul-MatoGrossense. Iheringia, Série Botânica 73: 1-87.

Tundisi JG, Tundisi TM. 2008. Limnologia. São Paulo, Oficina de Textos.

Web of Science. 2021. The world's largest publisher-neutral citation index and research intelligence platform. https://apps.webofknowledge.com. 07 Feb. 2021. 